\title{
Effect of Biomolecules from Human Renal Matrix of Calcium Oxalate Monohydrate (CaOx) Stones on In Vitro Calcium Phosphate Crystallization
}

\author{
Priyadarshini Pathak, Shrawan K. Singh, Chanderdeep Tandon \\ Biotechnology \& Bioinformatics (PP, CT), Jaypee University of Information Technology, Waknaghat, \\ and Department of Urology (SKS), Post Graduate Institute of Medical Education and Research, \\ Chandigarh, India
}

\begin{abstract}
Purpose: Investigate the activity of high and low molecular weight biomolecules present in the matrix of human calcium oxalate $(\mathrm{CaOx})$ stones not only on the initial mineral phase formation of calcium and phosphate $(\mathrm{CaP})$ but also on its growth and demineralization of the preformed mineral phase.

Materials and Methods: Surgically removed renal stones were analyzed by Fourier Transform Infra Red (FTIR) spectroscopy and only $\mathrm{CaOx}$ stones were extracted with 0.05M EGTA, $1 \mathrm{mM}$ PMSF and 1\% $\beta$-mercaptoethanol. Renal CaOx stone extract was separated into $>10 \mathrm{kDa}$ and $<10 \mathrm{kDa}$ fractions by dialysis. Activity of both the fractions along with whole extract was studied on the three mineral phases of CaP assay system.

Results: It was interesting to observe that both high and low molecular weight biomolecules extracted from human renal matrix of calcium oxalate $(\mathrm{CaOx})$ stones exhibited different roles in the three mineral phases of CaP. Whole extract exhibited inhibitory activity in all the three assay systems; however, mixed (stimulatory and inhibitory) activity was exhibited by the $>10 \mathrm{kDa}$ and $<10 \mathrm{kDa}$ fractions. SDS-PAGE analysis showed bands of $66 \mathrm{kDa}, 80 \mathrm{kDa}, 42 \mathrm{kDa}$ in whole EGTA extract lane and $>10 \mathrm{kDa}$ fraction lane.

Conclusion: Both high and low molecular weight biomolecules extracted from human renal matrix of calcium oxalate $(\mathrm{CaOx})$ stones have a significant influence on calcium and phosphate $(\mathrm{CaP})$ crystallization.
\end{abstract}

Key words: calcium phosphate; calcium oxalate; EGTA; brushite; organic matrix protein Int Braz J Urol. 2010; 36: 621-8

\section{INTRODUCTION}

Often calcium oxalate stones are mixed with various percentages of apatite or brushite, and some studies have shown that apatite is the principal component of Randall's plaque and the primary nidus at which calcium oxalate stones grow $(1,2)$. Pure apatite and brushite stones are composed of similar chemical components, calcium and phosphate, but the crystalline structure is different. The theoretical ratio of calcium and phosphate in brushite $\left[\mathrm{CaH}\left(\mathrm{PO}_{4}\right) \cdot 2 \mathrm{H}_{2} \mathrm{O}\right]$ is 1.0, and in apatite $\left[\mathrm{Ca}_{10}\left(\mathrm{PO}_{4}\right)_{6}(\mathrm{OH})_{2}\right]$ is 1.7 , though biological apatite often has a ratio less than these (3). A. Randall demonstrated that interstitial crystals located at, or adjacent to, the papillary tip, Randall's plaques, were common in stone formers. He found that these crystals were composed not of calcium oxalate, the most common solid phase found in patients with nephrolithiasis, but of calcium phosphate. He believed that the calcium phosphate crystals formed in the papillary interstitium and then eroded into the urinary space, serving as a heterogeneous nucleation surface for calcium oxalate (4). Romberg et al. have reported that macromolecular modifiers of calcium oxalate 
crystallization (5) are also active in the corresponding stages of calcium phosphate crystallization. The heterogeneous nucleation theory also underlines the importance of calcium phosphate crystals in calcium oxalate urolithiasis. All this evidence suggests that there is a close relationship between calcium phosphate and calcium oxalate. Any alteration in calcium phosphate binding protein may lead to the increased deposition of calcium oxalate, by acting as a nidus or calcium oxalate binding protein may influence calcium phosphate crystallization. The aim of the present work was to study the activity of biomolecules present in the organic matrix of calcium oxalate on calcium phosphate crystallization.

\section{MATERIALS AND METHODS}

Human renal stones were obtained from the Urology Department of Postgraduate Institute of Medical Education and Research (PGIMER), Chandigarh, India. Calcium oxalate stones were confirmed after Fourier Transform Infra Red (FTIR) spectroscopy analysis. All stones were of non-infectious nature. Chemicals were of analytical grade and were used without further purification. Reagents were made with deionized, distilled water.

\section{Extraction of Stones}

Surgically removed human renal stones (60 gms) were pooled and extracted for the study. $0.15 \mathrm{M}$ $\mathrm{NaCl}$ solution was used for washing the kidney stones to remove the adhered blood and tissue. They were then dried and pulverized with a mortar and pestle. The powder thus obtained was extracted with $0.05 \mathrm{M}$ EGTA, $1 \mathrm{mM}$ PMSF and $1 \% \beta$-mercaptoethanol. The extraction was carried out for 4 days at $4^{\circ} \mathrm{C}$ with constant stirring. The suspension was centrifuged for 30 minutes at $10,000 \mathrm{~g}$ and at $4^{\circ} \mathrm{C}$. The supernatant of EGTA extract was filtered through Amicon ultra centrifugal filter device with a molecular weight cut off 10,000 Daltons at $4^{\circ} \mathrm{C}$ and concentrated to a known volume. Whole EGTA extract, greater than and less than 10,000 Dalton fractions were stored at $-20^{\circ} \mathrm{C}$ for further studies (6).

\section{Protein Assay \& SDS-PAGE}

The protein concentration of each fraction was measured by the Bradford method (7). For SDSPAGE each fraction was lyophilized and reconstituted with sample buffer containing $\beta$-mercaptoethanol. Samples were heated to $95^{\circ} \mathrm{C}$ for $5 \mathrm{~min}$. and were submitted to electrophoresis using $1 \mathrm{~mm}$ thick, $12 \%$ separating and $4.4 \%$ stacking gels with a Mini-Protean III apparatus (Bio-Rad Laboratories). Broad range molecular weight markers (catalog \# 161-0317, Bio-Rad) were used as standards. Protein bands were stained with silver using ProteoSilver ${ }^{\mathrm{TM}}$ Plus Silver Stain Kit (PROTSIL2, Sigma-Aldrich Corp. Bangalore, India.).

\section{Homogeneous Assay System of Initial Mineral Phase of Calcium Phosphate}

To determine the activity of calcium phosphate $(\mathrm{CaP})$ precipitation, homogenous mineralization system was used to study the extent of in vitro mineral phase formation in the absence of any matrix (8). The $5 \mathrm{~mL}$ homogenous system consisted of 5 $\mathrm{mM} \mathrm{CaCl}_{2}$ and $5 \mathrm{mM} \mathrm{KH}_{2} \mathrm{PO}_{4}$, Tris buffer $(0.1 \mathrm{M}$ Tris and $210 \mathrm{mM} \mathrm{NaCl}[\mathrm{pH} 7.4]$ ) and distilled water. After incubating this system at $37^{\circ} \mathrm{C}$, precipitates obtained were centrifuged and the pellets were resuspended in $0.1 \mathrm{~N} \mathrm{HCl}(9)$. The calcium $\left(\mathrm{Ca}^{2+}\right)$ and phosphate ions $\left(\mathrm{HPO}_{4}{ }^{2-}\right)$ concentration in the precipitate represented the extent of precipitation (crystallization) of these ions and the biomolecule(s) will either minimize or maximize the extent of their precipitation. The $\mathrm{Ca}^{2+}$ and $\mathrm{HPO}_{4}{ }^{2-}$ ions were estimated by the methods of Trinder (10) and Gomori (11) respectively. Percentage inhibition or stimulation of mineral phase in the presence of kidney stone extract (whole extract, $>10$ $\mathrm{kDa} \&<10 \mathrm{kDa}$ fraction) was calculated as: \%age Inhibition $=[(\mathrm{C}-\mathrm{T}) / \mathrm{C}] \mathrm{X} 100$, where $\mathrm{T}$ is the concentration of $\mathrm{Ca}^{2+}$ or $\mathrm{HPO}_{4}^{2-}$ ion of the precipitate formed in the assay system with the kidney stone extract and $\mathrm{C}$ is the concentration of $\mathrm{Ca}^{2+}$ or $\mathrm{HPO}_{4}^{2-}$ ion of the precipitate formed in control system which had distilled water (Millipore (India) Pvt. Ltd., Bangalore, India). 


\section{Homogeneous Assay System of Growth and Demineralization of Calcium Phosphate Mineral Phase}

The growth and demineralization of preformed mineral phase consisting of calcium phosphate required initial precipitates of these minerals as obtained by the initiation of calcium phosphate mineral phase. To study the growth of the preformed mineral phase, the precipitates formed by the above method were resuspended in the same assay system having calcium and phosphate along with the three fractions of kidney stone extract. This assay system was incubated at $37^{\circ} \mathrm{C}$ for $30 \mathrm{~min}-$ utes. Then $\mathrm{Ca}^{2+}$ and $\mathrm{HPO}_{4}^{2-}$ ions were estimated and the concentration of these ions represented the growth of precipitation of these ions over the previously formed mineral phase.

For demineralization, the preformed mineral phase was resuspended in the assay system with all the three fractions of kidney stone extract but without further addition of calcium and phosphate ions. This assay system was incubated at $37^{\circ} \mathrm{C}$ for 30 minutes. $\mathrm{Ca}^{2+}$ and $\mathrm{HPO}_{4}{ }^{2-}$ ions were estimated in supernatant to determine the demineralization of mineral phase by all the three fractions of kidney stone extract.

In case of growth of pre-formed mineral phase, concentration of $\mathrm{Ca}^{2+}$ and $\mathrm{HPO}_{4}^{2-}$ ions was deducted from the final concentration of $\mathrm{Ca}^{2+}$ and $\mathrm{HPO}_{4}^{2-}$ ions. The percentage inhibition or stimulation caused by different fractions of renal extract was calculated with respect to control system, which had distilled water instead of kidney stone extract. In case of demineralization, the percentage inhibition of $\mathrm{Ca}^{2+}$ and $\mathrm{HPO}_{4}^{2-}$ ions demineralized, was calculated in supernatant.

\section{RESULTS}

\section{Initial Mineral Phase}

The $98.97 \%$ of phosphate ion inhibition was exhibited by the whole renal stone extract, $85.9 \%$ by $>10 \mathrm{kDa}$ and $92.09 \%$ by $<10 \mathrm{kDa}$ fraction on in vitro homogenous assay system of calcium phosphate (Figure-1A). However, whole extract showed maximum $81.64 \%$ of calcium ion inhibition. Interestingly both type of activity stimulatory (maximum $25.2 \%$ ) as well as inhibitory activity (maximum $25.01 \%$ ) was shown by $>10 \mathrm{kDa}$ fraction. $<10 \mathrm{kDa}$ fraction showed $96.23 \%$ of maximum inhibition (Figure-1B).

\section{Growth of Preformed Mineral Phase}

In cases where growth of preformed mineral phase percentage inhibition of phosphate ions increased with the increase of whole extract volume, $>$ $10 \mathrm{kDa}$ fraction stimulated the growth of phosphate ions on preformed mineral phase whereas $<10 \mathrm{kDa}$ showed both types of activity (Figure-2A).

Inhibition of calcium ions was shown by whole extract and $<10 \mathrm{kDa}$ fraction on the growth of preformed mineral phase. Stimulation was seen by various volumes of $>10 \mathrm{kDa}$ fraction (Figure-2B).

\section{Demineralization of Preformed Mineral Phase}

Release of phosphate ions increased with the increase of volume of different fractions. Maximum amount of phosphate was released with whole extract (Figure-3A). Percentage release of calcium ions were decreased with the increase of different extract volumes. Low volume of whole extract resulted in maximum release of calcium ions (Figure-3B).

\section{Protein Estimation \& SDS-PAGE}

Protein content of crude $(239.5 \mu \mathrm{g} / \mathrm{mL})$ and $>10 \mathrm{kDa}(154.8 \mu \mathrm{g} / \mathrm{mL})$ fraction was high. $<10 \mathrm{kDa}$ fraction had less $(72.6 \mu \mathrm{g} / \mathrm{mL})$ amount of protein.

SDS-PAGE analysis revealed a large number of bands mainly ( $66 \mathrm{kDa}, 80 \mathrm{kDa}, 42 \mathrm{kDa}$ ) in whole extract and in $>10 \mathrm{kDa}$ fraction (Figure-4). Faint bands of low molecular weight appeared in $<10 \mathrm{kDa}$ lane (not shown in the image).

\section{COMMENTS}

Urolithiasis is known to be an affliction to humankind from ancient eras (12) and is the third 
A

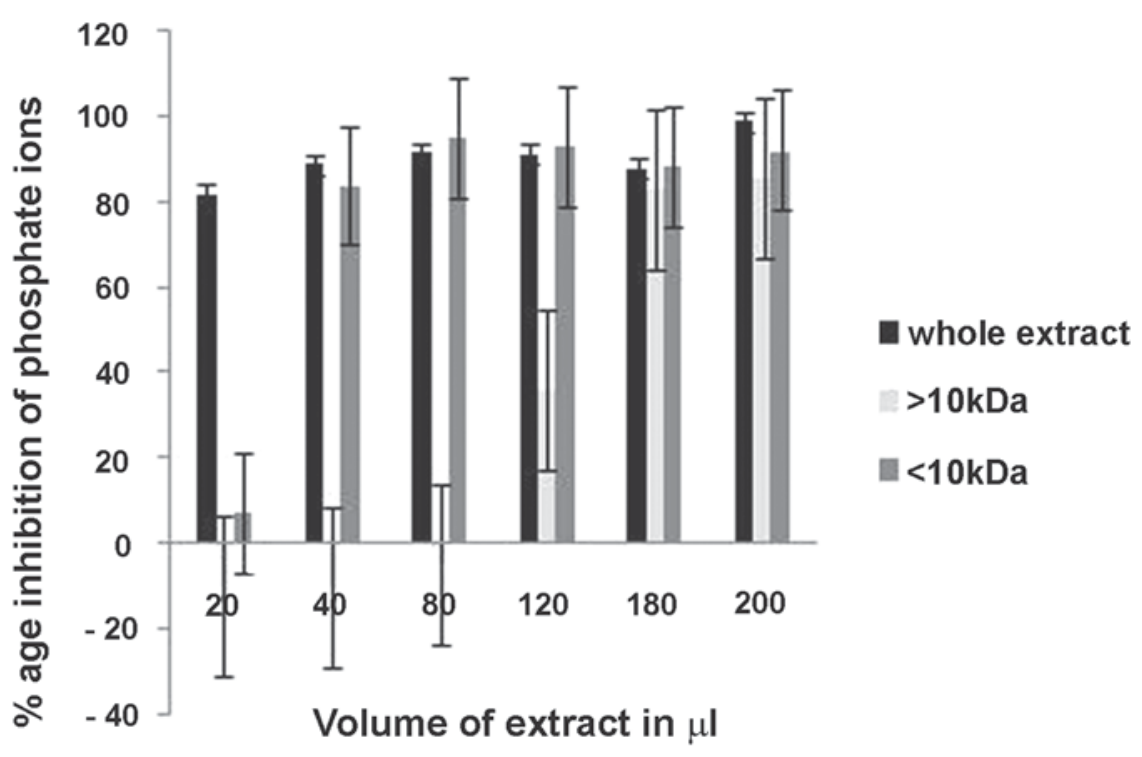

B

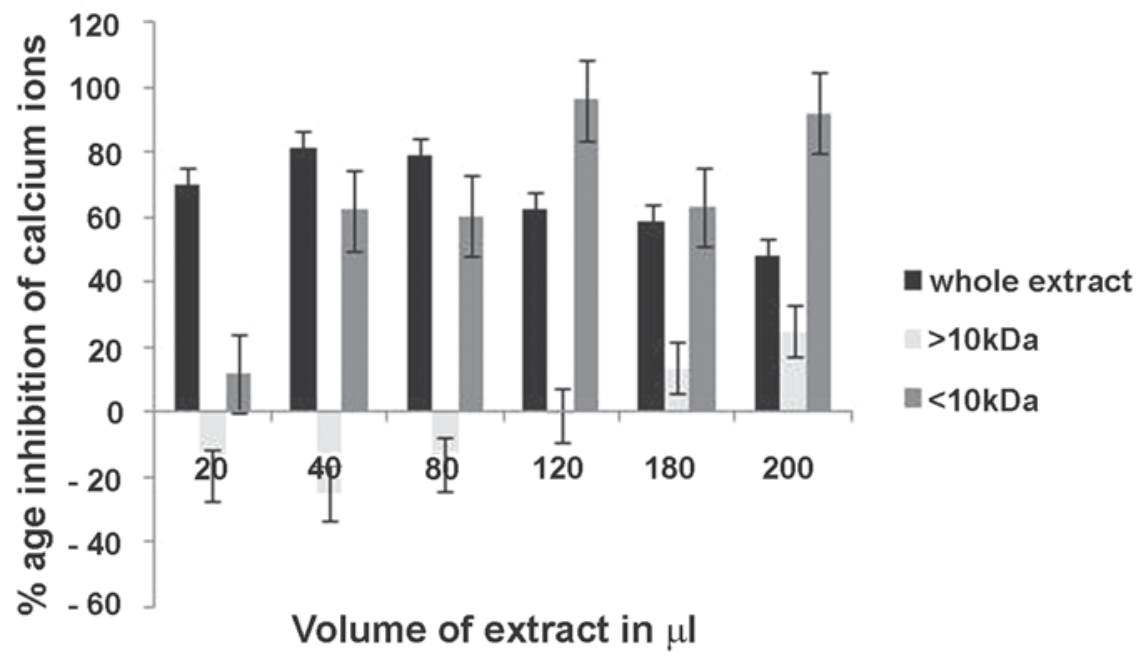

Figure 1 - Effect of various volumes of renal stone extract(whole extract, $>10 k D a,<10 k D a)$ on initial mineral phase. Percentage inhibition/stimulation of phosphate ions $(A)$ and calcium ions $(B)$ by different renal stone extracts.

most common cause of urinary tract disease (13). Among all types of kidney stones the frequency of calcium stone is $70-80 \%$, struvite stone $5-10 \%$, uric acid stone $5-10 \%$, and cystine stone $1 \%$ (14). Calcium oxalate is the primary component of $70-80 \%$ of calcium stones (15-17) with calcium phosphate being the predominant component in the rest of calcium stones. Calcium phosphate kidney stones include apatite (carbapatite or hydroxyapatite (HAP)), brushite (Bru) and octacalcium phosphate (OCP) with the occurrence rate of apatite, $4-10 \%$; Bru, 2-6\%; and octacalcium phosphate, less than $1 \%$ (14). A recent study has reported that the occurrence of calcium phosphate containing stones has increased over time (18). Calcium phosphate occurs in stones in several different forms: amorphous calcium phosphate (ACP), HAP, 
A

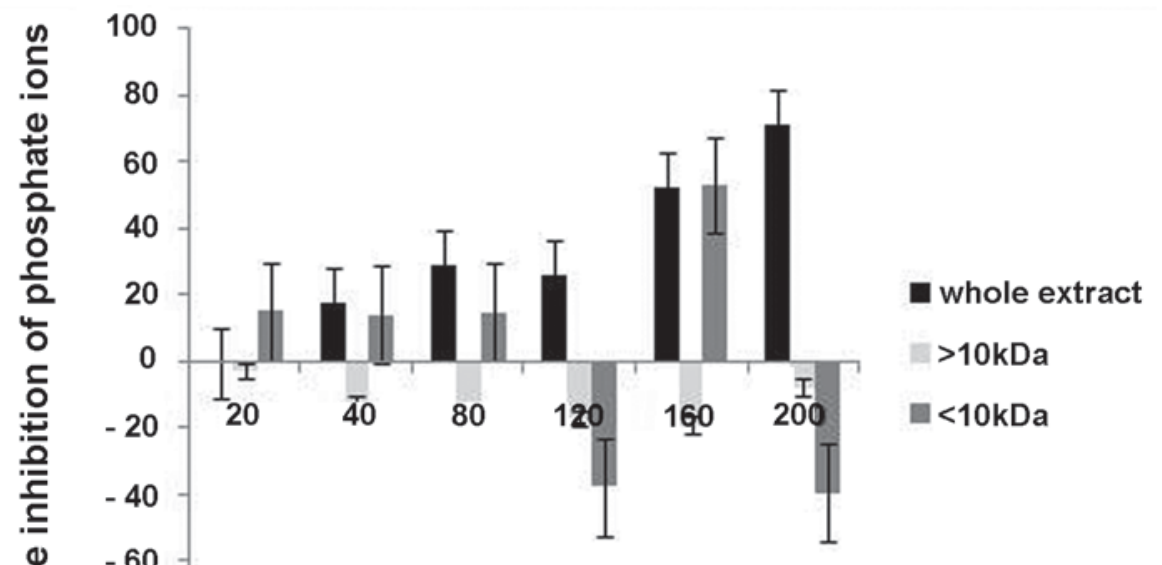

Volume of extract in $\mu \mathrm{l}$

B

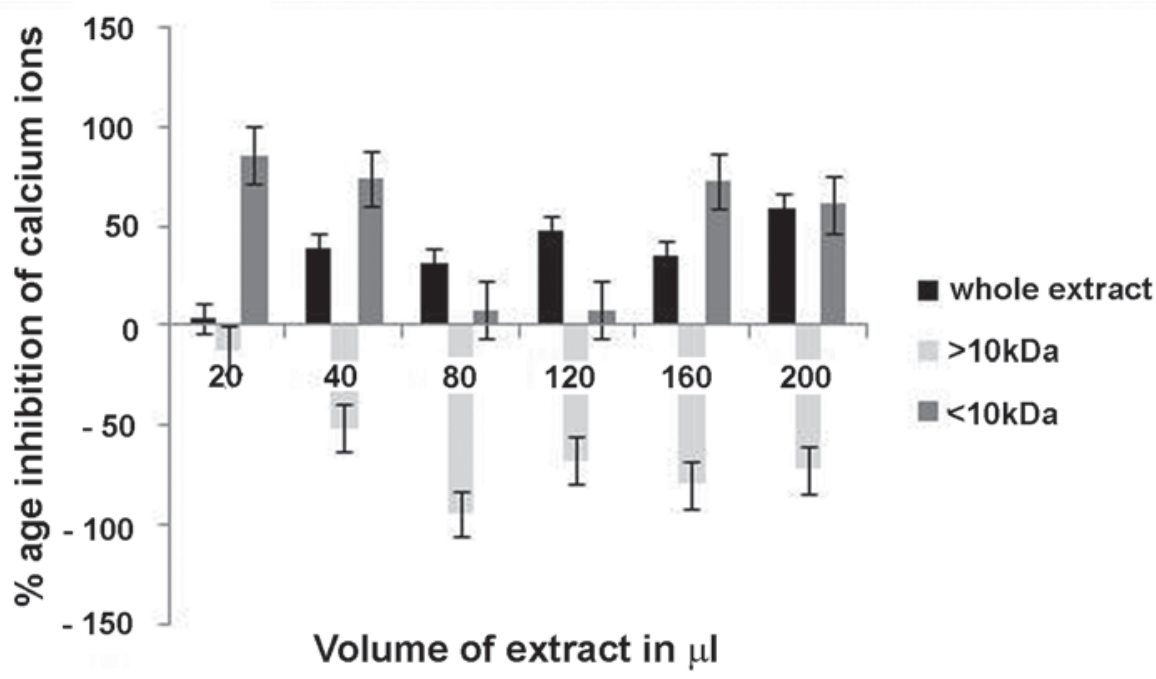

Figure 2 - Percentage inhibition or stimulation of phosphate ions (A) and calcium ions (B) by different volumes of whole extract, > $10 \mathrm{kDa}$ and $<10 \mathrm{kDa}$ fractions of renal stone extract on the growth of preformed mineral phase.

Bru, whitlockite, and carbonate apatite (CarbAp). The first product that precipitates is an ACP, which subsequently is converted to the crystal phases OCP and HAP or occasionally Bru. Hydroxyapatite is the thermodynamically most stable calcium phosphate crystal phase and it is also the major crystal phase in mixed calcium oxalate/calcium phosphate stones. Under certain conditions brushite (Bru; calcium hydrogen phosphate) is formed (19-21).
In this study we determined whether the renal calculi organic matrix biomolecules of calcium oxalate had any functional role in calcium phosphate crystallization. Whole EGTA extract exhibited inhibitory activity in initial and growth mineral phase. Stimulatory and inhibitory activity was shown by $>$ $10 \mathrm{kDa}$ fraction in initial mineral phase. Stimulatory activity was retained in growth mineral phase by this fraction. $<10 \mathrm{kDa}$ had inhibitory activity in initial 
A

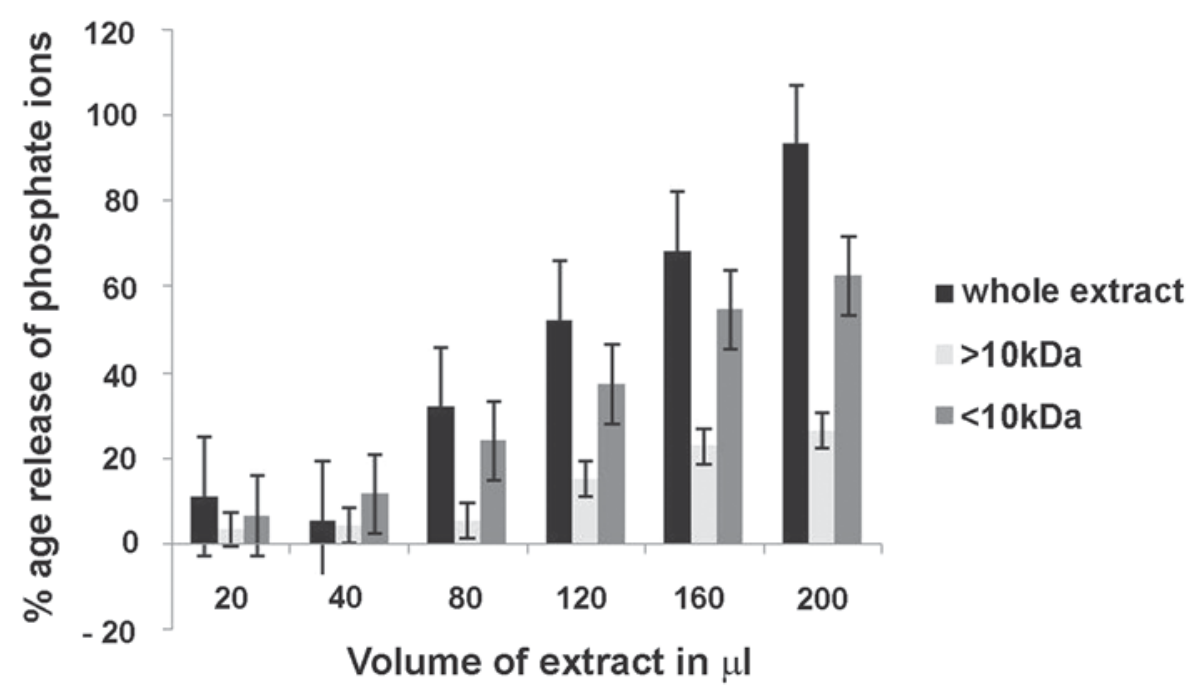

B

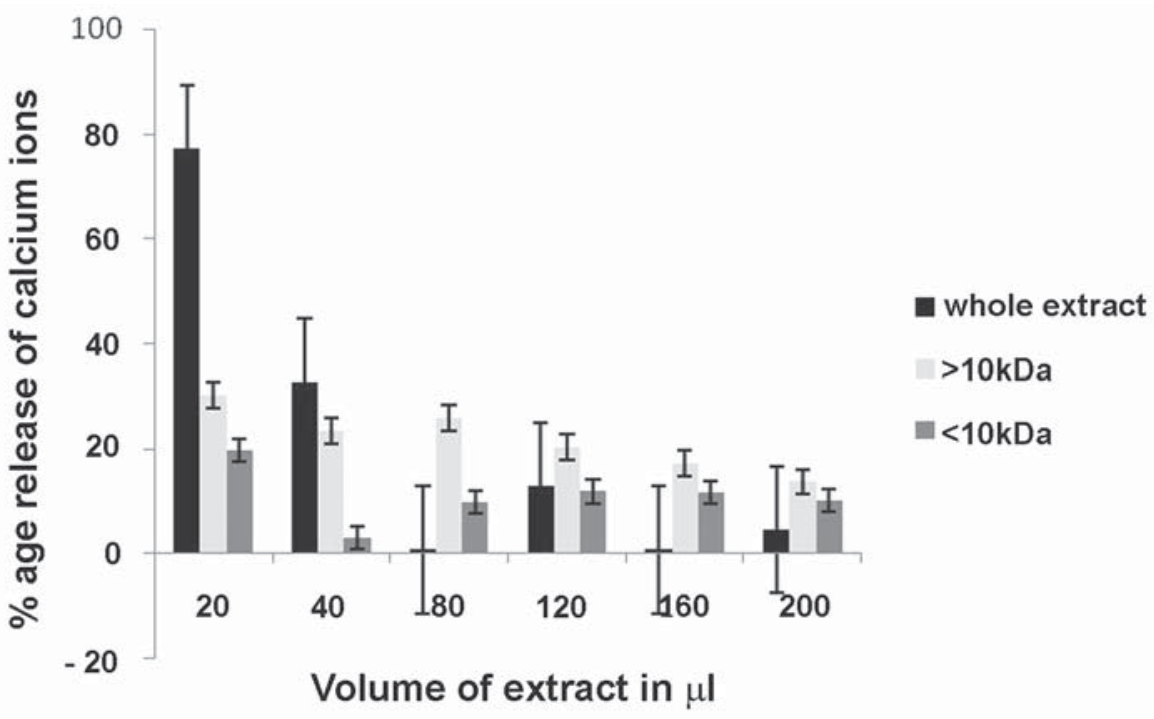

Figure 3 - Effect of various volumes of renal stone extract (whole extract, $>10 \mathrm{kDa},<10 \mathrm{kDa}$ ) on demineralization of preformed mineral phase. Percentage of phosphate ions $(A)$ and calcium ions $(B)$ demineralized by different fractions of renal stone extract.

mineral phase. Both types of activity was shown by $<10 \mathrm{kDa}$ fraction in growth mineral phase.

High percentage of phosphate ion was released with high volume of all the three fractions. However, the opposite trend was observed with calcium ion demineralization. It was found that high percentage of calcium ion was released with low volume of all the three fractions.

Romberg et al. have reported that macromolecular modifiers of calcium oxalate crystalliza- tion (4) are also active in the corresponding steps of calcium phosphate crystallization. There is, however, evidence that $\mathrm{Mg}$, citrate, and pyrophosphate are the most important inhibitors of calcium phosphate crystal growth.

There are reports explaining the activity of uric acid binding protein (22) and calcium phosphate binding protein (23) on calcium oxalate crystallization. The predominant proteins found in organic matrices of $\mathrm{CaOx}$ crystals induced in the urine of 


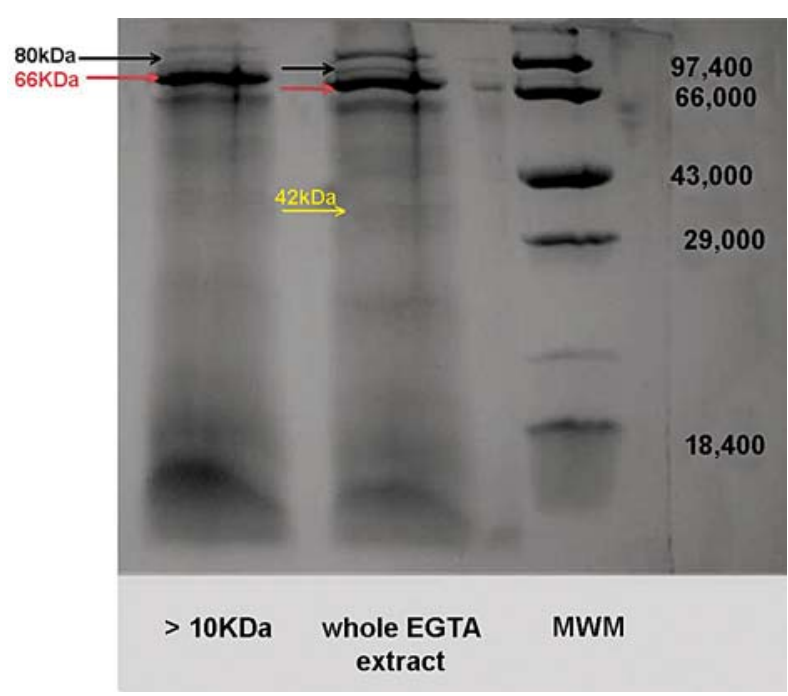

Figure 4-SDS-PAGE showing bands in whole EGTA extract and in $>10 \mathrm{kDa}$ fraction.

healthy controls were prothrombin-related proteins followed by albumin and osteopontin. In matrices of $\mathrm{CaP}$ crystals, the principal proteins were TammHorsfall protein followed by albumin, prothrombin-related proteins and osteopontin (24). In our study, besides other bands, SDS-PAGE analysis also showed bands of MW $\sim 66 \mathrm{kDa}, 80 \mathrm{kDa}$ and $42 \mathrm{kDa}$ in whole EGTA extract lane and $>10 \mathrm{kDa}$ fraction lane. Interestingly, their molecular weights are quite close to that of albumin, Tamm-horsfall protein and osteopontin/uropontin respectively. In our laboratory, very recently an anionic protein (MW $\sim 42 \mathrm{kDa}$ ) with potent inhibitory activity against $\mathrm{CaOx}$ crystal growth was purified. It was identified by MALDI-TOF-MS followed by database search on MASCOT server as human phosphate cytidylyltransferase $1, \AA$. Molecular weight of this novel $\mathrm{CaOx}$ crystal growth inhibitor from human renal stone matrix is also the same as that of human phosphate cytidylyltransferase 1 , choline, $\beta$ (25). Osteopontin (OPN) and Tamm-Horsfall protein (THP) are two major urinary macromolecules that exhibit various activities that can influence calcium crystallization in vitro $(26,27)$. OPN is a ubiquitously expressed phosphoglycoprotein that regulates bone biomineralization and ectopic calcification $(28,29)$.

Therefore, our study suggest that both high and low molecular weight biomolecules extracted from human renal matrix of calcium oxalate $(\mathrm{CaOx})$ stones have a significant influence on calcium and phosphate $(\mathrm{CaP})$ crystallization.

\section{ACKNOWLEDGEMENTS}

Jaypee University of Information Technology provided financial support to this research and the Department of Urology, Post Graduate Institute of Medical Education and Research, Chandigarh, India, provided the kidney stones.

\section{CONFLICT OF INTEREST}

None declared.

\section{REFERENCES}

1. Evan AP, Lingeman JE, Coe FL, Parks JH, Bledsoe SB, Shao Y, et al.: Randall's plaque of patients with nephrolithiasis begins in basement membranes of thin loops of Henle. J Clin Invest. 2003; 111: 607-16.

2. Matlaga BR, Williams JC Jr, Kim SC, Kuo RL, Evan AP, Bledsoe SB, et al.: Endoscopic evidence of calculus attachment to Randall's plaque. J Urol. 2006; 175 : 1720-4; discussion 1724.

3. Pramanik R, Asplin JR, Jackson ME, Williams JC Jr: Protein content of human apatite and brushite kidney stones: significant correlation with morphologic measures. Urol Res. 2008; 36: 251-8.

4. Bushinsky DA: Nephrolithiasis: site of the initial solid phase. J Clin Invest. 2003; 111: 602-5.

5. Romberg RW, Werness PG, Riggs BL, Mann KG: Inhibition of hydroxyapatite crystal growth by bonespecific and other calcium-binding proteins. Biochemistry. 1986; 25: 1176-80.

6. Aggarwal S, Tandon CD, Forouzandeh M, Singla SK, Kiran R, Jethi RK: Role of biomolecules from human renal stone matrix on COM crystal growth. Mol Cell Biochem. 2000; 210: 109-19.

7. Bradford MM: A rapid and sensitive method for the quantitation of microgram quantities of protein utilizing the principle of protein-dye binding. Anal Biochem. 1976; 72: 248-54.

8. Kabra SG, Kabra V, Banerji P, Jain LK, Bhargava A, Chaturvedi RP: In vitro calculogenesis: methods to 
develop concretions of desired chemical composition. Indian J Exp Biol. 1978; 16: 212-7.

9. Bijarnia RK, Kaur T, Singla SK, Tandon C: A novel calcium oxalate crystal growth inhibitory protein from the seeds of Dolichos biflorus (L.). Protein J. 2009; 28: 161-8.

10. Trinder P: Colorimetric microdetermination of calcium in serum. Analyst. 1960; 85: 889-94.

11. Gomori HD: A modification of colorimetric phosphorus determination for use with photoelectric colorimeter. J Lab Clin Med. 1941; 27: 955-960.

12. Miyaoka R, Monga M: Use of traditional Chinese medicine in the management of urinary stone disease. Int Braz J Urol. 2009; 35: 396-405.

13. Amaro CR, Goldberg J, Amaro JL, Padovani CR: Metabolic assessment in patients with urinary lithiasis. Int Braz J Urol. 2005; 31: 29-33.

14. Morton AR, Wooltorton E: Nephrology in practice: a new series. CMAJ. 2002; 166: 195.

15. Herring LC: Observations on the analysis of ten thousand urinary calculi. J Urol. 1962; 88: 545-62.

16. Mandel NS, Mandel GS: Urinary tract stone disease in the United States veteran population. II. Geographical analysis of variations in composition. J Urol. 1989; 142: 1516-21.

17. Tefekli A, Esen T, Ziylan O, Erol B, Armagan A, Ander $\mathrm{H}$, et al.: Metabolic risk factors in pediatric and adult calcium oxalate urinary stone formers: is there any difference? Urol Int. 2003; 70: 273-7.

18. Mandel N, Mandel I, Fryjoff K, Rejniak T, Mandel G: Conversion of calcium oxalate to calcium phosphate with recurrent stone episodes. J Urol. 2003; 169: 20269.

19. Leusmann DB, Niggemann H, Roth S, von Ahlen H: Recurrence rates and severity of urinary calculi. Scand J Urol Nephrol. 1995; 29: 279-83.

20. Györy AZ, Ashby R: Calcium salt urolithiasis. Review of theory for diagnosis and management. Clin Nephrol. 1999; 51: 197-208.

21. Hesse A, Heimbach D: Causes of phosphate stone formation and the importance of metaphylaxis by urinary acidification: a review. World J Urol. 1999; 17: 308-15.

22. Kalaiselvi P, Udayapriya KL, Selvam R: Uric acidbinding proteins in calcium oxalate stone formers and their effect on calcium oxalate crystallization. BJU Int. 1999; 83: 919-23.

23. Nishio S, Hatanaka M, Takeda H, Aoki K, Iseda T, Iwata $\mathrm{H}$, et al.: Calcium phosphate crystal-associated proteins: alpha-2-HS-glycoprotein, prothrombin fragment 1 and osteopontin. Int J Urol. 2001; 8: S58-62.
24. Atmani F, Khan SR: Quantification of proteins extracted from calcium oxalate and calcium phosphate crystals induced in vitro in the urine of healthy controls and stone-forming patients. Urol Int. 2002; 68: 54-9.

25. Priyadarshini, Singh SK, Tandon C: Mass spectrometric identification of human phosphate cytidylyltransferase 1 as a novel calcium oxalate crystal growth inhibitor purified from human renal stone matrix. Clin Chim Acta. 2009; 408: 34-8.

26. Devuyst O, Dahan K, Pirson Y: Tamm-Horsfall protein or uromodulin: new ideas about an old molecule. Nephrol Dial Transplant. 2005; 20: 1290-4.

27. Kumar V, Lieske JC: Protein regulation of intrarenal crystallization. Curr Opin Nephrol Hypertens. 2006; 15: 374-80.

28. Giachelli CM, Steitz S: Osteopontin: a versatile regulator of inflammation and biomineralization. Matrix Biol. 2000; 19: 615-22.

29. Mo L, Liaw L, Evan AP, Sommer AJ, Lieske JC, Wu XR: Renal calcinosis and stone formation in mice lacking osteopontin, Tamm-Horsfall protein, or both. Am J Physiol Renal Physiol. 2007; 293: F1935-43.

Accepted after revision: December 20, 2009

\section{Correspondence address:}

Dr. C. Tandon

Biotechnology and Bioinformatics Jaypee University of Information Technology Waknaghat, Solan, 173215, India

Tel: + 91981 622-6719

E-mail: tandonchanderdeep@yahoo.com 